\title{
The boundaries in the area of knowledge transfer in management consulting
}

\author{
Os fluxos de fronteira no campo da transferência de conhecimentos \\ em consultoria de gestão
}

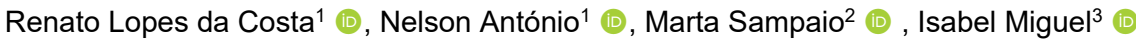 \\ ${ }^{1}$ Instituto Universitário de Lisboa - ISCTE, Lisboa, Portugal. E-mail: renatojlc@gmail.com; njsantonio@gmail.com \\ ${ }^{2}$ Universidade de Évora, Évora, Portugal. E-mail:martamotasampaio@gmail.com \\ ${ }^{3}$ Universidade de Coimbra, Faculdade de Economia, Coimbra, Portugal. E-mail: misabelsmiguel@gmail.com
}

How to cite: Costa, R. L., António, N., Sampaio, M., \& Miguel, I. (2021). The boundaries in the area of knowledge transfer in management consulting. Gestão \& Produção, 28(1), e4956.

https://doi.org/10.1590/1806-9649.2020v28e4956

\begin{abstract}
In a historical retrospective, although the existing literature calls the management consulting industry an extraordinary sector and a unique phenomenon in the business context, in fact these statements are not accompanied by a number of academic studies that emphasize the importance of the effective work of the management consultants. To contest the lack of studies in this emerging area, this article aims to understand the implications of the border to the transfer of information and knowledge from management consultants to their client companies. The results of the empirical analysis in the form of semi-structured interviews and questionnaires applied to management consultants and SME managers in Portugal reveal that the competency factor must be based on the four knowledge families of business management - the know- know, the competence, know-how and know-how to be and it is only from this conjugation that any kind of constraints that can be found along the way (political, physical or cultural) are able to be unblocked.
\end{abstract}

Keywords: Management consulting, Knowledge transfer; Strategy-as-practice.

Resumo: Numa retrospetiva histórica, embora a literatura existente apelide o setor de consultoria de gestão como um setor extraordinário e um fenómeno único no contexto empresarial, na verdade estas afirmações não vêm acompanhadas por um número de estudos académicos que realcem a importância do trabalho efetivo dos consultores de gestão. Para combater a falta de estudos nesta área emergente, este artigo visa perceber as implicações do fluxo de fronteira ao nível da transferência de informação e conhecimentos dos consultores de gestão para as suas empresas cliente. Os resultados da análise empírica sob a forma de entrevistas semiestruturadas e questionários aplicados a consultores de gestão e gestores de PME em Portugal demonstram que o fator competência deve ser alicerçado às quatro famílias de saberes da gestão empresarial - 0 saber-saber, o saber-empreender, o saber-fazer e o saber-ser, sendo que só a partir desta conjugação se podem desbloquear quaisquer tipos de constrangimentos (sejam estes de carácter político, físico ou cultural) que possam vir a ser encontrados pelo caminho.

Palavras-chave: Consultoria de gestão; Transferência de conhecimento; Estratégia-comoprática.

Received Jun. 30, 2019 - Accepted Jan. 05, 2020

Financial support: None.

This is an Open Access article distributed under the terms of the Creative Commons Attribution License, which permits

unrestricted use, distribution, and reproduction in any medium, provided the original work is properly cited. 


\section{Introduction}

As in other áreas of management domain, the evolution of the strategic disciplines in the organizations has been broadly diffused by the management consulting industry, this being the main reason why Canback (1998) describes this sector as the way to success which must be embraced by companies in the contextualization of their strategic orientation and their professionals as the true disseminators of the complex phenomenon of business evolution until today known.

This same thinking has been evidenced by several authors over the past few years defending the industry as an influential and powerful tool for organizational change, bringing a new life to organizations and their procedural chains.

In a historical retrospective, the benefits of the management consulting industry were already clear in terms of the influence and contribution they generated to the growth of industries in the 1950s (Stryker, 1954). For this reason has Drucker (1979) twenty-five years later named this as an extraordinary sector and a unique phenomenon in the business context and not only by the unique, singular, objective and independent aid that translates into the resolution of concrete problems (Greiner \& Metzger, 1983; Canback, 1999), but also by the experience that it transports and that appears many times associated to results related to high productivity (Fincham, 2010).

At an international level, although the progress and heterogeneity of the scientific studies carried out in recent decades in the area of strategic consulting by prestigious authors such as McGivern (1983), McLarty \& Robinson (1998), Fincham et al. (2009), Karantinou \& Hogg (2009), Werr \& Styhre (2002), Jackall (1988), Clark (2004), Jarzabkowski \& Paul Spee (2009), and Whittington (2007) are seen as added value, and here too, the strategy workers have not received much attention in the strategic field of research. Whittington (2007) gives an example of this, noting that no article on consulting in one of the major journals of the strategy such as the "Strategy Management Journal" had been published by 2007.

In a more practical section, although the recent strategy-as-practice (SAP) movement has implied some attention to the importance of consultants (Whittington, 2006; Jarzabkowski et al., 2007; Kaiser \& Kampe, 2005; Lundgren \& Blom, 2009), the latter with a high degree of greater exposure as it is presented on the international community's website of academics and practitioners of strategic as practice.

Thus, in order to combat the lack of studies in this emerging area, it is necessary to penetrate this market and to perceive this activity, bringing to the academic field a considerable amount of information that contributes in a concrete way to the development of this field of research and, one of the forms of is to perceive and define the characteristics and factors that lead to the identification of the identity of this industry, perceiving its relationship with the market in terms of knowledge, rather than identifying it only with a set of static techniques to be applied (Fincham \& Clark, 2002).

Taking into account the theme presented here, this study aims to relate two variables, the management consulting industry and its SME framework, in an attempt to define border in the field of knowledge transfer in management consulting.

In this sense, the present study seeks to contribute to the development of scientific knowledge in the management consulting sector through the following objectives: (1) to verify the impact of management consulting on the concepts of legitimacy and innovation of management consultants in works developed in SMEs; (2) perceive the implications of frontier at the level of transfer of knowledge from management consultants to their client firms; and (3) realize to what extent the flow of information and knowledge may or may not be blocked at boundaries information and knowledge in tax, cultural and political terms.

This article is divided into four parts. The first illustrates the theoretical basis of the topic, the second part through the presentation of the methodology inherent to the development of this research, the third based on the presentation of the results 
obtained and a fourth where the same will be discussed empirically. Finally, some final considerations about the study will also be presented.

\section{Literature review}

According to Argote et al. (2003) and Haas (2006), there has been a substantial body of literature between the 1980s and 2000s that has reflected the importance of knowledge for organizations, much of this knowledge transfer being emphasized in the role of external agents in terms of new information that they bring to companies creating crucial help in creating new organizational practices. Sturdy et al. (2009) present consultants as the real promoters of trends and ideas, which, when implemented, help to rationalize current and new jobs and the organizations themselves (O'Shea \& Madigan, 1998), reflecting consultants as specialists in terms of the new knowledge transfer of business management (ideas also defended by Merton, 1972; Guttman \& Willner, 1976; Gill \& Whittle, 1992; Zito, 1994; Hood, 1995; Bloomfield \& Danieli, 1995; Pollitt \& Bouckaert, 2000; Thrift, 2005; Handley et al., 2007).

This reflection is somehow defended also by McKenna (2006) when he describes the consultant as a "pre-eminent commissar of knowledge", based on the status it holds and the knowledge economies they bring to organizations when compared to the base and the internal cadres organizations. They therefore serve as a borderline between internal and external organizational management, which has been reflected in part in the paradigm of economic transaction costs, although in this case from a broader perspective, as is evident. This view of consultants as external experts is also presented in certain more skeptical studies on the robustness of knowledge in the consulting field (Brindle \& Stearns, 2001).

It can therefore be said that the consultant's view as an "external expert" is indeed transversal in terms of literature. If this theory is largely consistent with studies such as those by Semadeni (2001), it is equally true in more skeptical studies of the robustness of consultants' skills and knowledge (Brindle \& Stearns, 2001), who examine consulting as a system of persuasion and rhetoric (Clark, 1995) based on ambiguous knowledge (Alvesson, 2004) in an attempt to appeal to existential customer anxiety, the consultant is always portrayed as an "external expert", which undoubtedly reflects a certain degree of consensuality regarding the nature of the flow of the knowledge process - knowledge and organizational boundary (Sturdy et al., 2009).

In a first aspect the value of the consultant is based on the inherent status of an external agent to the organization, related to the necessary contribution that they bring to organizational learning in terms of knowledge (Antal \& Krebsbach-Gnath, 2001), on the other hand, it refers to the attention that an external agent with statute brings to the organization, focused on what Kipping and Armbrüster (2002) described as "promoters of promotional actions" which often results in customer resistance and explains the often lacking communication between both the so-called frontier of knowledge (Sturdy et al., 2009) that contrasts with the new knowledge base of Antal \& Krebsbach-Gnath (2001).

From this last analysis we can then identify two perspectives - the functionalist and the critical (Armbrüster, 2006). The critical perspective is therefore seen in a broad context of analysis, portraying a broad view of what consulting is actually about, pointing the functionalist towards a more micropolitical context, reflecting an alternative perspective on the innovative role of the consultancy in terms of organizational environment (Bloomfield \& Danieli, 1995; Jackall, 1988). In this latter case, the emphasis is placed on the legitimacy of existing customer knowledge, rather than the innovation that "expert" consultants may eventually bring to the organizational context. It is therefore a more conservative rather than innovative view in terms of the knowledge that is transferred to customers. 
But, according to Sturdy et al. (2009), this question is not as simple as it seems and in practice consultants can be both innovative and legitimating, and can bring out new knowledge based on a base legitimacy pertaining to the external consultant's own status, solving some of the problems faced by internal managers who often come across their ideas strangled by the lack of status they have for the simple reason that they are professionals within the organization (Sturdy \& Wright, 2008). According to Sturdy et al. (2009), the results may lie somewhere between innovation and legitimacy. Given this complexity, how can one conceptualize the process of knowledge flow or potential in consulting projects, and what does this effectively mean in the broader scope of analysis in terms of the role of the consultant?

Sturdy et al. (2009) respond to this same complexity in the article "Betweeen Innovation and Legitimation - Boundaries and Knowledge Flow in Management Consultancy" when authors cross information resulting from studies of knowledge flows across more generic organizational boundaries and apply this strand to a context of management consulting, which in fact allows them to perceive the impacts and implications of this type of analysis in the critical understanding of this topic in management consulting.

In the interpretation of this complexity and according to the boundary dimensions and typologies discussed from studies in the inter-organizational learning area and knowledge transfer, authors such as Orlikowski (2002), Szulanski (2003), Carlile (2004) and Nooteboom (2004), Sturdy et al. (2009) developed three types of boundary classification in relation to the knowledge flow - physical, cultural and political (Figure 1).

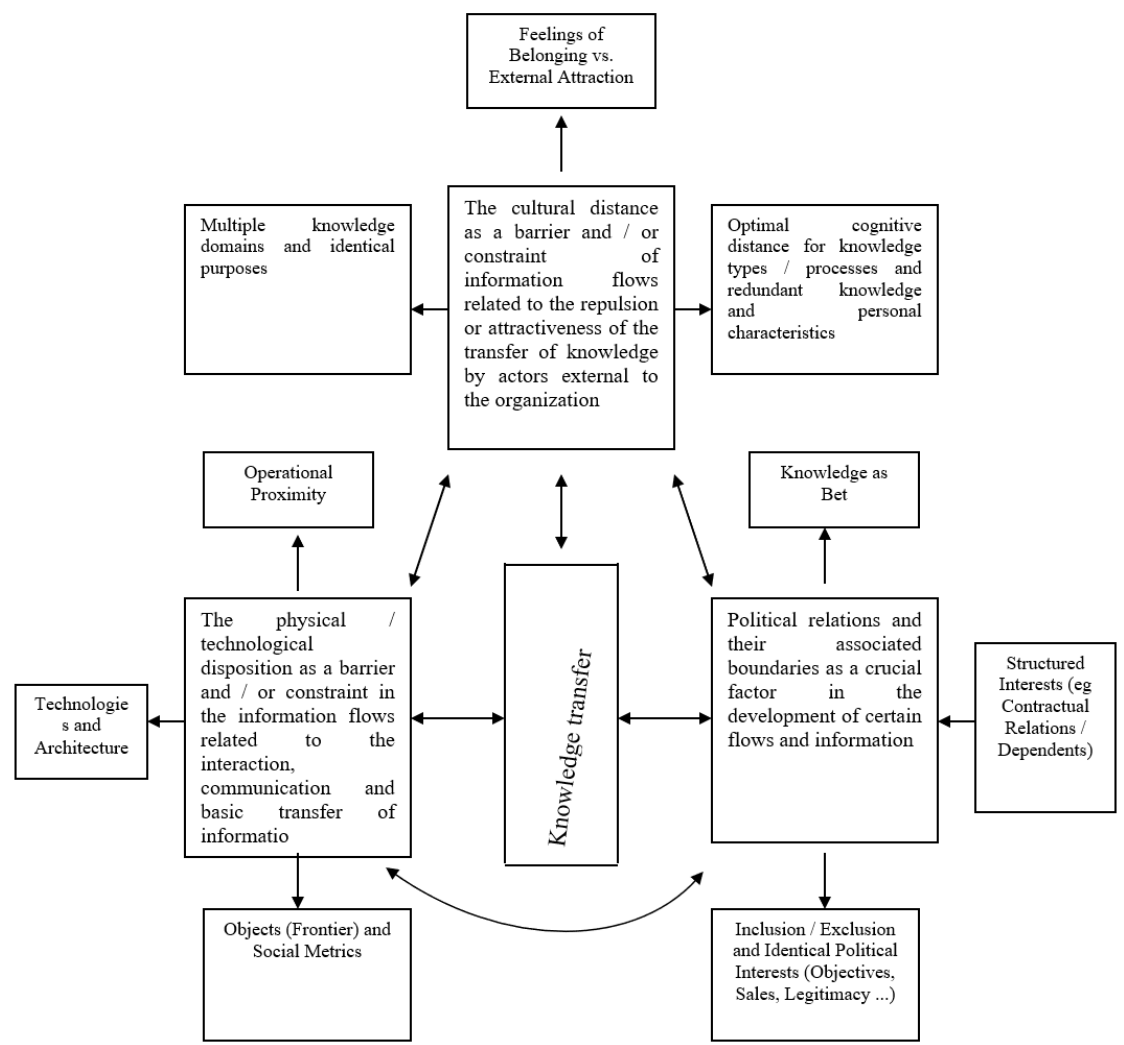

Figure 1. Physical, cultural and political boundary flows in the field of knowledge transfer. Source: Adapted from Sturdy et al. (2009). 
The physical dimension, like all boundaries, demands the attention that must be given to power, demonstrating a set of aspects to be considered, such as technological style, space, but also in terms of power (or lack of it) caused by exclusion or physical inclusion of the interaction. On the other hand, what this typology indicates to us is that operational proximity does not reflect on its own and does not give us any guarantee that knowledge can flow efficiently, but it may generate (or not) a greater possibility of socio-emotional identification, even because there are many success stories where joint project teams where clients and consultants are allocated in distant physical contexts sharing the same set of work activities, are able to obtain the necessary efficiency in the development of their work from the permanent contact they maintain (Clegg et al., 2004).

The cultural dimension is a complex phenomenon correlated with two dimensions, cognitive and emotional. That is, the potential for sharing social characteristics and understanding to facilitate the flow of new knowledge is clearly greater than the simple cognitive vision that is assumed, since it is clearly related also to emotions and feelings of belonging and/or identity to group. This view can be further complemented by the social similarities among actors that derive from different social and cultural backgrounds that make them up and that can make information flows and knowledge transfer easier to obtain from actors who share the same set of social characteristics, personal relationships and the same common language domain (Semadeni, 2001; Gluckler \& Armbrüster, 2003).

Communication or contact, differences in knowledge, close personal relationships and the sharing of characteristics do not in themselves imply a guarantee of knowledge flow, which in a broader perspective leads to a greater material notion of power and interests, that is, to the political dimension as a factor also to consider. Such interests include consideration of structural differences and dependency relationships with and between organizations, for example, the inclusion of new practices can effectively be imposed on subordinate units as subsidiaries of certain multinational corporations, organizational departments or, more often, employees (Kostova \& Roth, 2002). The same is to say, that in consulting, dependency relationships may vary, favoring in certain contexts the client, in others the consulting firm and, in others, certain individual actors (Fincham, 1999), so it is concluded that the flow of information is not necessarily a matter of establishing shared values or purposes as some suggest (Inkpen \& Tsang, 2005), but also portrays power relations that vary between compulsion and, in most cases, dependent/subordination, behavioral submission Child \& Rodrigues, 1996).

When combined different diversities of actors and the respective roles they assume, with the different types of existing borders, it is therefore an ambiguous situation, since what is legitimacy for some may be innovation for others, which is reflected in a certain way in recent reports of the "Management Consultancies Association" in the United Kingdom (MCA, 2016). For example, if we are talking about a set of certain clients with relative sophistication in terms of their familiarity with various forms of knowledge management, what consultants can bring is seen as legitimacy or confirmation of existing ideas. Similarly, in less well-known client organizations for management discourse, the arrival of consultants and the construction of project teams are more linked to the introduction of innovation or new practices and ideas (Sturdy et al., 2009).

What is important is not to have a generalized view, especially when the consultants are presented as providers of "specialized knowledge", but rather to specify more precisely the bases and dynamics of knowledge frontiers and their inclusion/exclusion effects (Sturdy et al., 2009). What is important is in fact retaining the idea that frontiers and knowledge flows are more complex and dynamic than the persistent and popular image of consultancy suggested by some as being a simple rhetoric masked between innovation and legitimacy. 


\section{Methodology}

As far as the means is concerned, the present investigation was based on a pragmatic or inductive character, and was conducted from a non-probabilistic sample for convenience, constituted according to the availability and accessibility of the elements addressed (Carmo \& Ferreira, 1998), in this case by management consultants and senior managers of Portuguese SMEs. In this sense, 300 questionnaires were sent to SMEs and 350 to management consultants (including 50 independent consultants) via e-mail. We returned 37 questionnaires from SME managers and 29 from management consultants, totaling 66 questionnaires filled with a response rate of $10.15 \%$.

However, considering that the interest of this research was centered in discovering the meaning and represent experiences of multiple realities, it was also used as a qualitative method of analysis 17 interviews, 9 to senior management consultants and 8 to managers of SMEs in Portugal, and the sample at the interview level was intentional, since the participants that best represented the phenomenon investigated in terms of knowledge were selected.

In terms of the qualitative analysis technique used to interpret the reproduced data from the interviews, this was translated into a content analysis, trying to relate the semantic (meaningful) structures with the sociological structures (meanings) of the statements, in order to articulate the text surface with the factors that determine their features - psychosocial variables, cultural context and context, processes and reproduction of the message (Figure 2).

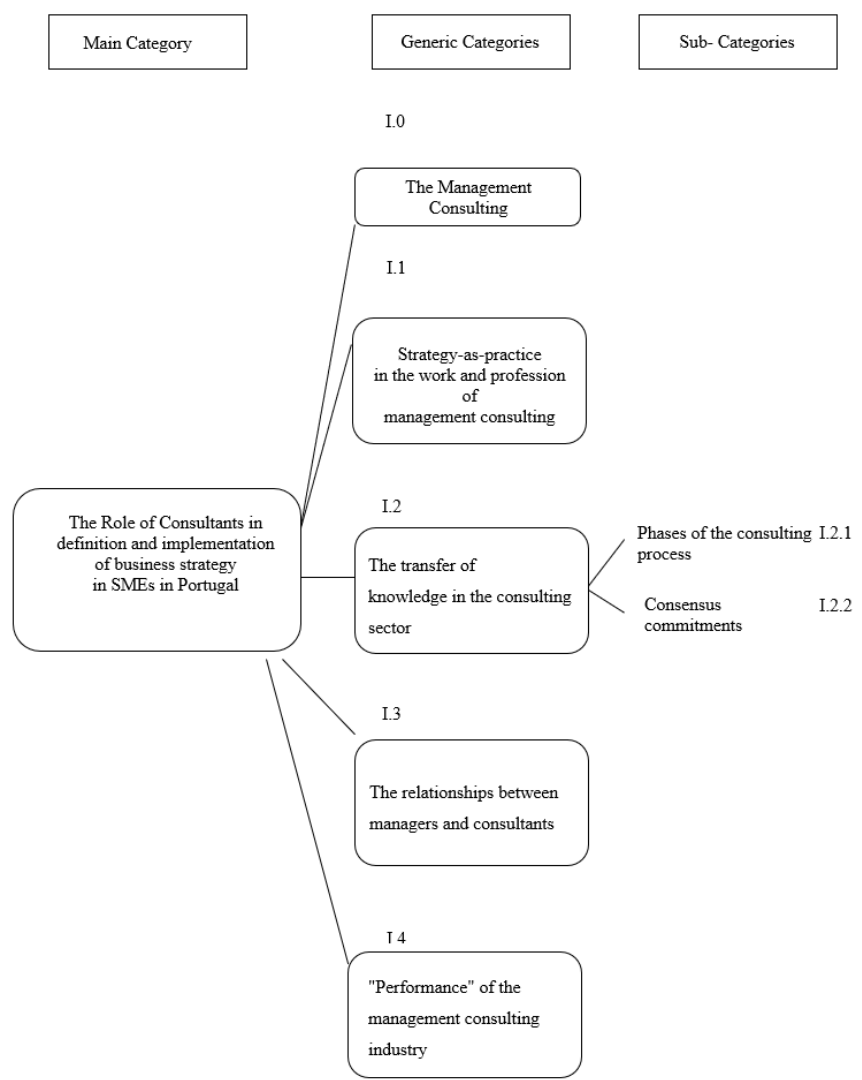

Figure 2. Categorization and coding of the interview corpus for qualitative analysis. 
In summary, this research was based on a set of primary sources, from the application of surveys in the form of 17 semi-structured interviews to 9 consultants and 8 managers of SMEs, and from the application of questionnaires with open and closed questions to 29 consultants and 37 SME managers from Lisbon, Douro, Leiria, Setúbal, Madeira, Minho, Beira Alta and Algarve (Portugal), being the representative sample of a group of respondents predominantly male $(63 \%)$, whose ages an average arithmetic value of 37 years. Almost all respondents are educated with a higher education level and have been working in their current companies on average for about 8 years. It should also be noted that the sample at the SME level is fundamentally linked to the retail and consulting area in the most diverse sectors of activity that make up the business management area.

\section{Resarch results}

If it is important to identify the stages of a consultancy process, it is important to understand the opinion of the respondents in terms of the impact of management consultancy in SMEs on the concepts of legitimacy and innovation. Are they more linked to a guarantee of innovation or legitimacy/status/expertise?

It can be concluded from reading Figure 3 and Table 1 that the results can be somewhere between innovation and legitimacy, with the introduction of a third axis of analysis - competence, where neither legitimacy nor innovation can fit in their entirety.

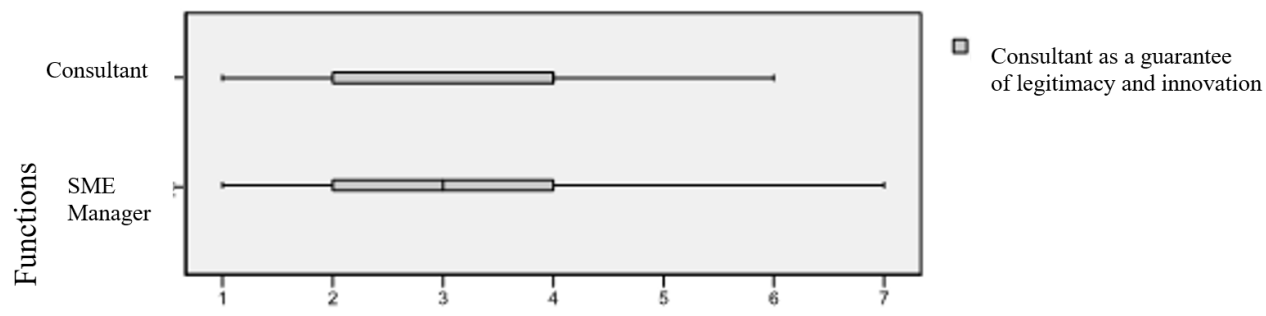

Figure 3. Evaluation of the respondents [consultants and clients (managers)] on how to define the impact of management consultancy in SME - innovation vs. legitimacy.

Given this complexity, it was also pertinent to approach this issue in accordance with the knowledge flow process at a more generic organizational frontiers level of Sturdy et al. (2009), Orlikowski (2002) and Szulanski (2003), in order to understand the implications of this type and at the same time to realize the extent to which the flow of information and knowledge may or may not be blocked at the frontiers of the flow of information and knowledge in physical, cultural and political terms (Figure 4).

Through the reading of Figure 4, the physical, cultural and political borders are not considered as important barriers to knowledge and information transfer flows between consultants and clients, being in the limit considered as constraints to this same flow. In detail, through reading the content analysis of respondents' responses (Table 2), they perceived this fact, being at most these boundaries considered as constraints. It was also concluded that cultural issues are those that can, however, involve greater concerns, even though they are situations that can be overcome with flexibility and adaptability, because, believe the respondents, the sector is based on a structure of credibility and knowledge that has the capacity to change the culture of companies and to increase the added value potential that can provide them, also resulting in improved acceptance of managers regarding the work of consultants (Figure 5 and 6). 
Table 1. Content analysis - innovation, legitimacy and competence as the three basic approach axes in the management consulting industry.

\begin{tabular}{|c|c|c|c|}
\hline \multicolumn{4}{|c|}{ Content Analysis - Interviews } \\
\hline Interviewee & Interviewee & Interviewee & $\begin{array}{l}\text { Sub } \\
\text { Categoria }\end{array}$ \\
\hline Consultant 1 & $\begin{array}{l}\text { To assess consultant would introduce there the } \\
\text { variable competence. }\end{array}$ & 1.1 & 1.1 .4 \\
\hline Consultant 6 & $\begin{array}{l}\text { So he separated the next. From the point of } \\
\text { view of the practices on the one hand there } \\
\text { is the competence aspect of the consultant } \\
\text { personally, and good procedural practices. If } \\
\text { we look at the variable of competencies, } \\
\text { then there I believe an excellent power of } \\
\text { communication. }\end{array}$ & 1.1 & 1.1 .5 \\
\hline Consultant 3 & $\begin{array}{l}\text { Then we enter the various subject areas of } \\
\text { the company. That is why we have the } \\
\text { quality systems, which the company usually } \\
\text { does not have, feel this need, or through the } \\
\text { market, or through the strategy, or through } \\
\text { its positioning, to bring and acquire this set } \\
\text { of skills. So you get someone who can do } \\
\text { that work. }\end{array}$ & 1.0 & \\
\hline Manager 3 & $\begin{array}{l}\text { Then what is more normal, that they bring } \\
\text { us the skills that we do not develop } \\
\text { internally. }\end{array}$ & 1.0 & \\
\hline Manager 2 & $\begin{array}{l}\text { We can see if there are any flaws. And from } \\
\text { there if we detect a fault we lose } \\
\text { confidence. So above all in this type of } \\
\text { projects, effectively the competence and } \\
\text { technical capabilities for safety. }\end{array}$ & 1.1 & 1.1 .5 \\
\hline Manager 6 & $\begin{array}{l}\text { Therefore, what could improve was without } \\
\text { doubt a better use of people's competence } \\
\text { and focus specifically on those areas where } \\
\text { they are experts. }\end{array}$ & 1.4 & 1.4.1 \\
\hline
\end{tabular}

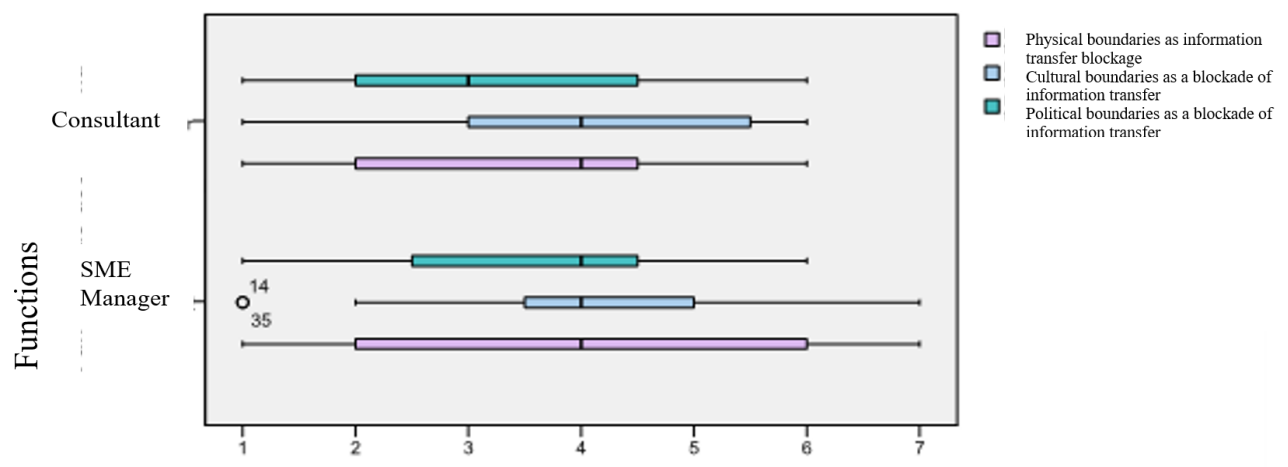

Figure 4. Evaluation of respondents [consultants and clients (managers)] on how to define the impact of management consulting in SMEs - physical, cultural and political organizational boundaries. 
Table 2. Content analysis - physical, cultural and political boundaries as constraints in terms of blocking information flows between consultants and clients.

\begin{tabular}{|c|c|c|c|}
\hline \multicolumn{4}{|c|}{ Content Analysis - Interviews } \\
\hline Interviewee & Interviewee & Interviewee & Interviewee \\
\hline Consultant 1 & $\begin{array}{l}\text { Of course there are some constraints that arise, } \\
\text { even if you can not consider them as barriers. } \\
\text { The way you approach a given problem with the } \\
\text { customer or how the data is exposed may in } \\
\text { some way create some problem, now constraints } \\
\text { related to physical barriers do not exist. The } \\
\text { presence of the consultant for example in the } \\
\text { company is agreed with each client. If, for } \\
\text { example, there are meetings. In cultural terms } \\
\text { there have never been any problems ... That is, } \\
\text { there is always a need to adapt to the client. }\end{array}$ & 1.2 & I.2.3 \\
\hline Consultant 3 & $\begin{array}{l}\text { At the level of organizational culture and } \\
\text { knowledge culture, there may also be obstacles } \\
\text { here. That is, I transmitted a certain message, } \\
\text { and by the cultural level of the person and the } \\
\text { knowledge of it is not properly understood, and } \\
\text { therefore, we will have a skewed result. These } \\
\text { kinds of constraints exist with some frequency ... } \\
\text { But I would say it's all a matter of message. }\end{array}$ & 1.2 & I.2.3 \\
\hline Consultant 4 & $\begin{array}{l}\text { This does not know if it damages the flow of } \\
\text { information, because it depends on the culture of } \\
\text { the organization itself. Above all, the consultant } \\
\text { has to be a flexible person, who knows very well } \\
\text { who is on the other side. }\end{array}$ & 1.2 & I.2.3 \\
\hline Consultant 6 & $\begin{array}{l}\text { From the cultural point of view, I think it is up to the } \\
\text { consultant to adapt himself to the local culture. } \\
\text { Either he has this ability or there will be constraints }\end{array}$ & 1.2 & I.2.3 \\
\hline Manager 4 & $\begin{array}{l}\text { The result does not believe it is affected. But } \\
\text { there are several anecdotes about the } \\
\text { consultant. This is always seen as someone } \\
\text { coming in from the outside, but I do not think it } \\
\text { has any influence in terms of providing } \\
\text { information. }\end{array}$ & 1.2 & 1.2 .3 \\
\hline Manager 5 & $\begin{array}{l}\text { Using the analogy that if people do not speak the } \\
\text { same language is very complicated (culture). }\end{array}$ & 1.2 & I.2.3 \\
\hline Manager 1 & $\begin{array}{l}\text { Cultural barriers I do not think so. There is a lack } \\
\text { of knowledge of our business. Because each } \\
\text { client has a specificity. }\end{array}$ & 1.2 & 1.2 .3 \\
\hline
\end{tabular}

Do clients believe in consultancy?

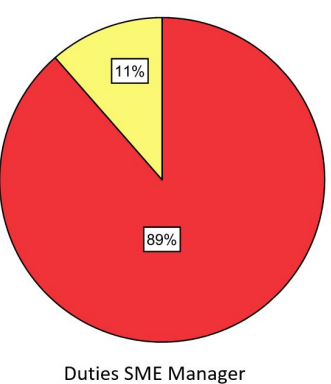

Duties SME Manager

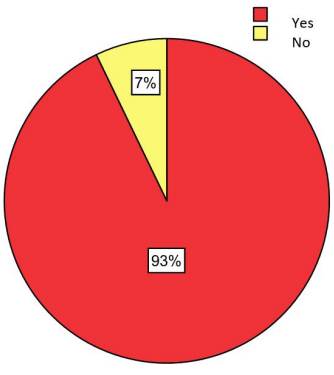

Functions of the Consultant

Figure 5. Evaluation of the respondents [consultants and clients (managers)] against the credibility of the consulting sector (yes - it is credible, no - it is not credible). 


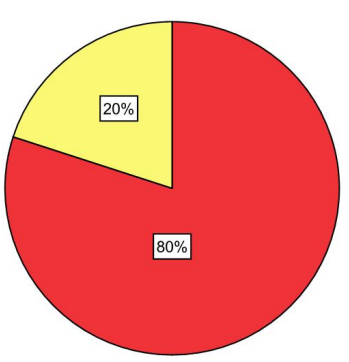

Duties SME Manager

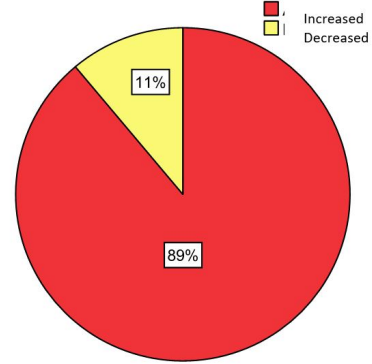

Functions of the Consultant

Figure 6. Evaluation of respondents [consultants and clients (managers)] in the face of improved managerial acceptance of consultants 'work (yes - managers' attitude increased in relation to future work with consultants; no - managers' attitude has not increased in the face of future work with consultants).

\section{Results discussion}

From the data observed in this research it seems to be clear that although the consultants may not be synonymous or meaningful in their true sense of the word [contrasting with versions made by O'Shea \& Madigan (1998), McKenna (2006), or Semadeni (2001)], the truth is that management consulting functions in the business system as a crucial aid to the creation of new organizational practices (Haas, 2006) and to the promotion of new fashions and ideas (Sturdy et al., 2009).

It is important, however, to mention that although the consultants may be of crucial importance to the creation of new organizational practices and to the promotion of new fashions and ideas, this does not mean by itself that this guarantees them simultaneously the titling of innovators and because the legitimacy is based on the statute and this is not always considered as a guarantee of the consultant, especially in projects where the consultant is more connected to activities of base and procedural nature or redesignation of processes.

This same finding was illustrated in this research, citing respondents that SME consultants are more closely linked to a guarantee of innovation (Clark, 1995; Fincham \& Clark, 2002) than legitimacy (Jackall, 1988; Bloomfield \& Danieli, 1995), since the legitimacy, in addition to being linked to the status and to the methodologies and technical and practical aspects of the transfer of knowledge, involves both work capacity, expertise, experience and competence, and this type of they can measure the results. That is, the results may indeed be somewhere between innovation and legitimacy (Fincham et al., 2009), but for this it is necessary to introduce here a third axis of analysis - competence (Figure 7).

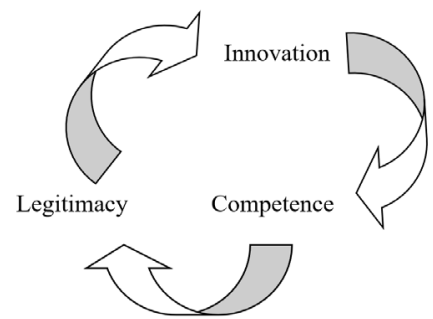

Figure 7. Consulting approach. Source: Elaborated by the author. 
Competence in this area should be seen as the ability of the consultant to mobilize and put into practice a set of validated and required theoretical and practical knowledge to master a work situation in different dimensions and not only to reside in the resources (knowledge, capacities) to mobilize, but in the mobilization of these same resources to meet an efficient performance, which should contemplate and incorporate the four families "of knowledge - the know- know, the competence, know-how and know-how to be, where neither legitimacy nor innovation is fully integrated.

This approach also brings to the heart of the issue the process of knowledge flow, here based on the organizational boundaries of the frontier model of Sturdy et al. (2009) - physical, cultural and political. According to the research, of the three frontiers, the one involving cultural issues is what may still involve higher levels of concern about these same constraints, given that it is a complex phenomenon correlated with the cognitive and emotional dimensions (emotions and feelings of belonging and/or identity to a particular group), and with social similarities among actors, which can lead to different social and cultural backgrounds and make knowledge transfer and knowledge flows less easy to obtain from of actors who share a different set of social characteristics, personal relationships, and language mastery (Gluckler \& Armbrüster, 2003; Semadeni, 2001).

In this case, as mentioned by the interviewed consultants, the secret to overcome such constraints must be the flexibility and the need for a great capacity to adapt to local cultures or the companies themselves, with rigor and demand, in a structured and quality way. That is, personal problems are only possible to dissipate with selfconfidence and self-motivation, causing problems of cultural roots such as beliefs and prejudices to be left aside, even dissipating possible leadership problems that may arise as a consequence of this.

At the level of the physical dimension, the physical exclusion of the interaction and the non-existence of operational proximity are also evaluated by the respondents as not worrying because they do not mean that knowledge can not flow efficiently, even by the existence of proven cases in which joint work teams, allocated in distant physical contexts but sharing a same set of work activities, were able to obtain the necessary efficiency to the development of their activities on the basis of a permanent contact that they maintained during the project period (as referred by Clegg et al., 2004). It should be noted, however, that there were cases where physical barriers actually meant constraints. As one manager said, "While we are in Lisbon, sometimes it is not easy to set up an urgent meeting with someone who may be based in the north". The same could be verified at the level of projects involving interlocutors between Portugal and Africa, given the difficulty that existed at the communication level. That is, although the physical constraint may actually be a barrier, it is very relative, and for the respondents and interviewees in this investigation the physical barriers did not mean exclusion or inefficiency.

Regarding structural issues, in terms of dependency relations with and between organizations, also referred to as power relations dependent or not dependent according to Child \& Rodrigues (1996), these were designated by respondents and interviewees as, of the three, less problematic, which can be explained by the ease of the consultants in identifying in SMEs the person who is the leader in the organization and who, from the media point of view, has a greater exposure, and from the outset can establish the power relationship which will be based on the relationship that will be built. That is, once the project leader in an SME is synchronized with the objective of the work, the question of power does not even arise, because even if it exists it would 
be putting everything at stake, entering into a defensive relationship of both the parts that would make the project quickly die. In fact, as we have seen, where power relations can be found, it is at the level of intermediate management, with resistance and fears being encountered, which at SME level is seldom encountered.

So the important thing is not to take a generalist view, and the most important thing is to focus attention not so much on the level of information flow and more on the interpretation of this same information and on the interpretation of what can be done of it, similar to that suggested by Whittington $(2006,2007)$, and Jarzabkowski \& Paul Spee (2009), in terms of the logical perspective of the field of strategy-as-practice study, and the important thing is to know the structuring elements of practice during the process of a strategy, but even more important is to understand the application and interpretation of these same practices.

\section{Final considerations}

While it seems clear that the consulting industry is built on credibility and knowledge, and has the ability to change the corporate culture (customer) and to increase the value-added potential it can provide them in terms of volume of business, and profitability, through expertise, experience, competence, effort and ability to work in the way they manage and conduct their work, and which is nowadays seen in much of the literature as the process of diffusion of innovations and the source of development of ideas, regardless of the different categories where their areas of action can be included, this does not guarantee by itself that the consultants can be called innovators and legitimizers.

Between innovation and legitimacy it is necessary to introduce a third variable, the competence factor based on the four families of knowledge of business management the know-know, the competence, know-how and know-how to be, being that only way this can be unblocked by any type of constraint found along the way (political, physical or cultural), while at the same time generating the flexibility, adaptability, rigor, the crucial aid so often required by them in terms of the creation of new organizational practices and the promotion of new fashions and ideas that may be introduced in their organizational spheres.

In this way, it can be seen that the assumption of excellence can be contained in the range of sharing and networking, with the different mental structures of the actors, combined with the variety of technical methods and concepts of the consultants and with the deep knowledge of the business of internal managers, translate what can be called the "triangle of success".

It is important, however, to take into account that the findings presented in this study are the result of limitations inherent in a small investigation in terms of sample size (respondents) and the fact of reproducing results in a given context (SMEs) in a given country (Portugal).

In this sense, in terms of external validity, i.e. the possibility of generalizing the results found to other contexts or samples, although this study has reinforced some of the existing theory regarding the concept of management consulting, this was only an exploratory study that cannot be generalized or representative.

On the other hand, although the secondary sources have been used and other analyses have been elaborated to complete the results, this factor cannot justify that the results presented here can be seen as necessarily generalizable in terms of the consulting practice. 
Another of the limitations was related to the impossibility of observing "in loco" clientconsultant interactions and, therefore, the consequent peculiarities of problems, ideas and techniques that could result from this same interaction.

Although this article aims fundamentally to combat the lack of studies on the management consulting industry, it is necessary to continue to breach this market and to perceive this activity, bringing to the academic field a considerable amount of information that brings above all originality and contribute in a concrete way to the development of this field of research.

One of the ways to respond to this gap is to focus, establish and institutionalize the practices and activities used in the management consulting industry and their implications in terms of organizational results, seeking to obtain a set of new developments in construction of literature with the introduction of new theoretical and empirical perspectives in this area.

In short, it is important to extend these studies to a deeper basis on all these subjects, in order to explore the future of the nature of practices, activities, stages and relationships in the management consulting industry, and future research to include in this sense the construction of a model that allows to relate all these variables, in order to be able to identify which one is more determinant for the success of a management consulting project. The ongoing task of the study of the sector must not forget also the impact that all this can have downstream of the chain, namely to the level of satisfaction of the client companies with the work done by the consultants and of the suggestions they advise for the improvement of the achievements.

\section{References}

Alvesson, M. (2004), Knowledge work and knowledge intensive firms. Oxford. Oxford University Press.

Antal, A., \& Krebsbach-Gnath, C. (2001). Consultants as agents of organisational learning. In M. Dierkes, A. B. Antal, J. Child \& I. Nonaka (Eds.), Handbook of organizational learning and knowledge. Oxford. Oxford University Press.

Argote, L., McEvily, B., \& Reagans, R. (2003). Managing knowledge in organizations: an integrative framework and review of emerging themes. Management Science, 49(4), 571582. http://dx.doi.org/10.1287/mnsc.49.4.571.14424.

Armbrüster, T. (2006). The economics and sociology of management consulting. Cambridge: Cambridge University Press. http://dx.doi.org/10.1017/CBO9780511488467.

Bloomfield, B., \& Danieli, A. (1995). The role of management consultants in the development of information technology: the indissoluble nature of socio-political and technical skills. Journal of Management Studies, 32(1), 23-46. http://dx.doi.org/10.1111/j.14676486.1995.tb00644.x.

Brindle, M., \& Stearns, P. (2001). Facing up to management faddism: a new look at an old force. Connecticut: Quorum Books.

Canback, S. (1998). The logic of management consulting (part one). Journal of Management Consulting, 10(2), 3-11.

Canback, S. (1999). The logic of management consulting (part two). Journal of Management Consulting, 10(3), 3-12.

Carlile, P. (2004). Transferring, translating and transforming: an integrative framework for managing knowledge across boundaries. Organization Science, 15(5), 555-568. http://dx.doi.org/10.1287/orsc.1040.0094. 
Carmo, H., \& Ferreira, M. (1998). Metodologia da investigação: guia para auto-aprendizagem. Lisboa: Universidade Aberta.

Child, J., \& Rodrigues, S. (1996). The role of social identity in the international transfer of knowledge through joint ventures. In S. Clegg \& G. Palmer (Eds.), The politics of management knowledge. London: Sage.

Clark, T. (1995), Managing consultants: consultancy as the management of impressions. Buckingham: Open University Press.

Clark, T. (2004). Strategy viewed from a management fashion perspective. European Management Review, 1(1), 105-111. http://dx.doi.org/10.1057/palgrave.emr.1500004.

Clegg, S. R., Kornberger, M., \& Rhodes, C. (2004). Noise, parasites and translation: theory and practice in management consulting. Management Learning, 35(1), 31-44. http://dx.doi.org/10.1177/1350507604041163.

Drucker, P. (1979), Why management consultants? In Z. Melvin \& R. G. Greenwood (Eds.), The evolving science of management. New York: Amacom.

Fincham, R. (1999). The consultant-client relationship: critical perspectives on the management of organizational change. Journal of Management Studies, 36(3), 335-352. http://dx.doi.org/10.1111/1467-6486.00139.

Fincham, R. (2010). The client in the client-consultant relationship. In M. Kipping \& T. Clark (Eds.), The Oxford handbook of management consultancy. Oxford. Oxford University Press.

Fincham, R., \& Clark, T. (2002). Preface: management consultancy: issues, perspectives and agendas. International Studies of Management \& Organization, 32(4), 3-18. http://dx.doi.org/10.1080/00208825.2002.11043673.

Fincham, R., Clark, T., Handley, K., \& Sturdy, A. (2009). Configuring expert knowledge: the consultant as sector specialist. Journal of Organizational Behavior, 29(8), 1145-1160. http://dx.doi.org/10.1002/job.559.

Gill, J., \& Whittle, S. (1992). Management by panacea: accounting for transience. Journal of Management Studies, 3(2), 281-295. http://dx.doi.org/10.1111/j.1467-6486.1993.tb00305.x.

Gluckler, J., \& Armbrüster, T. (2003). Bridging uncertainty in management consulting - the mechanisms of trust and networked reputation. Organization Studies, 24(2), 269-297. http://dx.doi.org/10.1177/0170840603242004.

Greiner, L., \& Metzger, R. (1983). Consulting to management. Englewood Cliffs: Prentice-Hall.

Guttman, D., \& Willner, B. (1976). The shadow government. New York: Pantheon Books.

Haas, M. (2006). Acquiring and applying knowledge in transnational teams - The roles of cosmopolitans and locals. Organization Science, 17(3), 367-384. http://dx.doi.org/10.1287/orsc.1060.0187.

Handley, K., Clark, T., Fincham, R., \& Sturdy, A. (2007). Researching situated learning: Participation, identity and practices in client-management consultant relationships. Management Learning, 38(2), 173-191. http://dx.doi.org/10.1177/1350507607075774.

Hood, C. (1995). The new public management in the 1980s: variations on a theme. accounting. Organizações \& Sociedade, 20(2), 93-109.

Inkpen, A., \& Tsang, E. (2005). Social capital, networks and knowledge transfer. Academy of Management Review, 30(1), 146-165. http://dx.doi.org/10.5465/amr.2005.15281445.

Jackall, R. (1988). Moral Mazes: the world of corporate managers. Oxford: Oxford University Press.

Jarzabkowski, P., \& Paul Spee, A. (2009). Strategy-as-practice: a review and future directions for the field. International Journal of Management Reviews, 11(1), 69-95.

http://dx.doi.org/10.1111/j.1468-2370.2008.00250.x. 
Jarzabkowski, P., Balogun, J., \& Seidl, D. (2007). Strategizing: the challenges of a practice perspective. Human Relations, 60(1), 5-27. http://dx.doi.org/10.1177/0018726707075703.

Kaiser, S., \& Kampe, T. (2005). A strategy-as-Practice Perspective on the Work of Profession of Strategy Consultants. In EGOS: Professional Service Organizations and Professionalization at Work. Berlin: EGOS.

Karantinou, K., \& Hogg, M. (2009). An empirical investigation of relationship development in professional business services. Journal of Services Marketing, 23(4), 249-260. http://dx.doi.org/10.1108/08876040910965584.

Kipping, M., \& Armbrüster, T. (2002). The burden of otherness: limits of consultancy interventions in historical case studies. In L. Engwall \& M. Kipping (Eds.), Management consulting: emergence and dynamics of aknowledge industry. Oxford: Oxford University Press.

Kostova, T., \& Roth, K. (2002). Adoption of an organizational practice by subsidiaries of MNCs: institutional and relational effects. Academy of Management Journal, 45(1), 215-233.

Lundgren, M., \& Blom, M. (2009). The practice of strategy consultants. In 25th Egos Colloquium. Barcelona: ESADE Business School.

Management Consultancies Association - MCA. (2016). "Management Consultancies Association" in the United Kingdom. London: MCA. https://www.mca.org.uk/report/ukconsulting-industry-statistics-2016-data-set.

McGivern, C. (1983). Some facets of the relationship between consultants and clients in organizations. Journal of Management Studies, 20(3), 367-386. http://dx.doi.org/10.1111/j.1467-6486.1983.tb00213.x.

McKenna, C. (2006), The world's newest profession. Cambridge: Cambridge University Press. http://dx.doi.org/10.1017/CBO9780511511622.

McLarty, R., \& Robinson, T. (1998). The practice of consultancy and a professional development strategy. Leadership and Organization Development Journal, 19(5), 256-263. http://dx.doi.org/10.1108/01437739810234323.

Merton, R. (1972). Insiders and outsiders: a chapter in the sociology of knowledge. American Journal of Sociology, 78(1), 9-47. http://dx.doi.org/10.1086/225294.

Nooteboom, B. (2004). Inter-firm collaboration, learning and networks: an integrated approach. London: Routledge.

O'Shea, J., \& Madigan, C. (1998). Consultoras: os bons e os maus conselhos. Executive Digest , 39(27), 215.

Orlikowski, W. (2002). Knowing in practice: enacting a collective capability in distributed organizing. Organization Science, 13(3), 249-273. http://dx.doi.org/10.1287/orsc.13.3.249.2776.

Pollitt, C., \& Bouckaert, G. (2000). Public management reform: a comparative analysis. Oxford. Oxford University Press.

Semadeni, M. (2001). Towards a theory of knowledge arbitrage: examining management consultants as knowledge arbiters and arbitragers. In A. F. Buono (Ed.), Current trends in management consulting: research in management consulting. Greenwich: Information Age Publishing.

Stryker, P. (1954). The ambitious consultants. Fortune, 82-85.

Sturdy, A., \& Wright, C. (2008). A consulting diaspora? Enterprising selves as agents of enterprise. Organization, 15(3), 427-444. http://dx.doi.org/10.1177/1350508408088538.

Sturdy, A., Clark, T., Fincham, R., \& Handley, K. (2009). Between innovation and legitimation: boundaries and knowledge flow in management consultancy. Organization, 16(5), 627-653. http://dx.doi.org/10.1177/1350508409338435.

Szulanski, G. (2003). Sticky knowledge: barriers to knowing in the firm. London: Sage. 
Thrift, N. (2005). Knowing capitalism. London: Sage.

Werr, A., \& Styhre, A. (2002). Management consultants friend or foe? International Studies of Management \& Organization, 32(4), 43-66. http://dx.doi.org/10.1080/00208825.2002.11043670.

Whittington, R. (2006). Completing the practice turn in strategy research. Organization Studies, 27(5), 613-634. http://dx.doi.org/10.1177/0170840606064101.

Whittington, R. (2007). Strategy practice and strategy process: family differences and the sociological eye. Organization Studies, 28(10), 1575-1586. http://dx.doi.org/10.1177/0170840607081557.

Zito, A. (1994). Epistemic communities in European policy making (Tese de doutoramento). Pittsburg University, Pittsburgh. 